NAMA : Nur Afifah Baharuddin

NIM $\quad: 70200120054$

KELAS : KSM D 2020

\title{
KEK PADA WANITA USIA SUBUR
}

\section{PENDAHULUAN}

Masalah gizi adalah masalah kesehatan masyarakat yang penanggulangannya belum pernah tuntas di dunia (Bardosono, 2009). Indonesia mengalami masalah gizi ganda yang artinya ketika masalah gizi kurang masih mendominasi dan belum tuntas, sudah muncul masalah gizi lebih, sehingga dikatakan Indonesia memiliki permasalahan gizi yang rumit (Widya Karya Nasional Pangan dan Gizi, 2004; Global Nutrition Report, 2014). Bahkan permasalahan gizi tersebut disebut sebagai intergenerational impact karena dapat memengaruhi status gizi pada periode kehidupan selanjutnya (Kemenkes RI, 2012). Wanita dan anak-anak merupakan kelompok yang memiliki risiko paling tinggi mengalami kurang energi kronis (KEK) (Kemenkes RI, 2010).

Berdasarkan Survei Demografi dan Kesehatan Indonesia (SDKI) tahun 2012, angka kematian Ibu (AKI) di Indonesia masih tinggi sebesar 359 per 100.000 kelahiran hidup. Angka ini mengalami kenaikan yang signifikan dari hasil SDKI 2007 yaitu AKI sebesar 228 per 100.000 kelahiran. Perdarahan menempati persentase tertinggi penyebab kematian Ibu sebesar 2 31,85\%. Anemia dan KEK pada ibu hamil menjadi penyebab utama terjadinya pendarahan dan infeksi yang merupakan faktor kematian utama ibu (Kemenkes RI, 2010).

Masa pra konsepsi merupakan masa sebelum hamil yang diasumsikan sebagai wanita dewasa atau wanita usia subur (WUS) yang siap menjadi seorang ibu. Status gizi prakonsepsi akan memengaruhi kondisi kehamilan dan kesejahteraan bayi yang akan lebih baik jika pencegahannya dilaksanakan pada saat sebelum hamil. Wanita usia 20-35 merupakan usia sasaran yang paling tepat dalam pencegahan masalah gizi terutama KEK yang merupakan keadaan ketika seseorang menderita ketidakseimbangan asupan gizi yang berlangsung menahun terutama pada wanita usia subur termasuk remaja putri (Cetin, 2009; Supariasa, 2012). 
Status gizi WUS salah satunya dipengaruhi oleh pola konsumsi. Pola konsumsi juga berpengaruh terhadap status kesehatan ibu, dimana pola konsumsi yang kurang baik dapat menimbulkan suatu gangguan kesehatan pada ibu (Supariasa, 2012). Jika jumlah pola konsumsi makanan selama satu hari dengan porsi empat sehat lima sempurna, maka pola konsumsi tersebut terukur dalam kategori baik. Sedangkan terukur dalam keadaan cukup jika hanya empat sehat, dan kurang jika hanya nasi dan lauk saja (Almatsier, 2003). MC Putri - 2017 - digilib.unila.ac.id

Anemia pada ibu hamil sangat berpengaruh terhadap kualitas manusia yang akan dilahirkan dan kualitas sumber daya manusia (SDM) generasi yang akan datang. Selain itu, anemia pada ibu hamil dapat meningkatkan kejadian abortus, prematus, berat badan lahir rendah (BBLR), serta dapat menyebabkan kematian pada ibu hamil pada waktu dan sesudah melahirkan. Anemia merupakan masalah yang dialami oleh 41,8\% ibu hamil di dunia. Sekitar setengah dari kejadian anemia tersebut disebabkan karena defisiensi besi. Adapun prevalensi anemia pada ibu hamil di dunia yaitu diperkirakan Afrika sebesar 57,1\%, Asia 48,2\%, Eropa 25,1\% dan Amerika 24,1\% (WHO 2015). S Syarfaini, S Alam, S Aeni, H Habibi, NA Novianti - Al-sihah: The Public Health ..., 2020

Berdasarkan data Riskesdas (2007), proporsi wanita usia subur berisiko KEK usia 15-19 tahun yang hamil sebesar 31,3\% dan yang tidak hamil sebesar 30,9\%. Pada usia 20-24 tahun yang hamil sebesar 23,8\% dan yang tidak hamil sebesar 18,2\%. Pada usia 25-29 tahun yang hamil sebesar $16,1 \%$ dan yang tidak hamil sebesar 13,1\%. Pada usia 30-34 tahun yang hamil sebesar $12,7 \%$ dan yang tidak hamil sebesar $10,2 \%$.

Berdasarkan data Riskesdas (2013), proporsi WUS risiko KEK mengalami peningkatan yaitu usia 15-19 tahun yang hamil sebesar 38,5\% dan yang tidak hamil sebesar 46,6\%. Pada usia 20-24 tahun adalah sebesar 30,1\% yang hamil dan yang tidak hamil sebesar 30,6\%. Selain itu, pada usia 25-29 tahun adalah sebesar 20,9\% yang hamil dan 19,3\% yang tidak hamil. Serta pada usia 30-34 tahun adalah sebesar 21,4\% yang hamil dan 13,6\% yang tidak hamil. MC Putri - 2017 digilib.unila.ac.id

Kurang Energi Kronik (KEK) pada ibu hamil masih menjadi permasalahan kesehatan di Indonesia. Prevalensi ibu hamil dengan risiko KEK di Indonesia masih tergolong tinggi yaitu 21,6\%. Berdasarkan pengambilan data di Puskesmas Dawan I, prevalensi ibu hamil dengan KEK yaitu 6,2\%. Untuk mencegah risiko KEK pada ibu hamil sebelum kehamilan, wanita usia subur 
(WUS) sudah harus mempunyai gizi yang baik, misalnya dengan LILA tidak kurang dari $23,5 \mathrm{~cm}$. P Stephanie, SKA Kartika - Bali: FK Unud, 2014 - sinta.unud.ac.id

Prevalensi risiko KEK penduduk WUS 15-49 tahun menurut provinsi tahun 2013, untuk Indonesia menunjukkan angka 24,2\% pada wanita hamil, 20,8\% pada wanita tidak hamil, dan secara khusus di Provinsi Lampung 4 sebesar 21,3\% pada wanita hamil dan 17,5\% pada populasi WUS tidak hamil (Riskesdas dalam Angka Final, 2013).

Berdasarkan latar belakang tersebut, peneliti tertarik untuk mengetahui apakah ada hubungan antara asupan makan dengan kejadian kurang energi protein (KEK) pada wanita usia subur (WUS) di Kabupaten Lampung Tengah. MC Putri - 2017 - digilib.unila.ac.id

\section{STATUS GIZI WUS}

Anemia dalam kehamilan adalah kondisi ibu dengan kadar Hemoglobin ( $\mathrm{Hb}$ ) dalam darah lebih rendah dari $11 \mathrm{gr} / \mathrm{dl}$. Angka anemia pada kehamilan di Indonesia menurut Riskesdas tahun 2013 sekitar 37,1\%. 26,4\% WUS di Indonesia mengalami anemia ( $\mathrm{Hb}<12 \mathrm{~g} / \mathrm{dl})$. Prevalensi anemia tertinggi pada WUS yang lebih tua, umur 40-49 tahun (28,7\%) kemudian diikuti oleh WUS umur 15-19 tahun (26,5\%). WUS dengan status kawin mempunyai prevalensi anemia lebih tinggi dibanding yang belum kawin. Sedang menurut wilayah, prevalensi anemia WUS di desa lebih tinggi dibanding yang di kota. Menurut kawasan, prevalensi anemia paling tinggi Sumatera, disusul Jawa dan Bali kemudian Kawasan Indonesia Timur (KTI). Makin muda umur WUS makin KEK (IMT<18,5), sebaliknya makin tua umur WUS makin gemuk/obesitas (IMT > 25,0). Prevalensi WUS yang banyak mengalami KEK (IMT< 18,5) adalah gol. Umur 15-19 tahun, disusul gol. Umur 20-29 tahun. Untuk WUS yang gemuk/obesitas (IMT > 25,0) terlihat paling banyak pada gol. Umur 40-49 tahun, diikuti umur 30-39 tahun. Pada Gambar 4 tampak 13,6\% WUS dengan status KEK dan 16,8\% gemuk/obesitas. WUS yang berstatus tidak kawin KEK (IMT=22,5\%) lebih tinggi dari WUS yang berstatus kawin (IMT=9,8\%). Di perdesaan WUS yang mengalami KEK (IMT=14, 3\%) lebih tinggi dari WUS yang di perkotaan (IMT=12,8\%). Untuk Kawasan Timur Indonesia paling tinggi persentase KEK pada WUS dibanding kawasan lainnya. D Bisara, S Supraptini, T Afifah - Indonesian Bulletin of Health ..., 2003 - media.neliti.com 


\section{POLA MAKAN WUS}

Berdasarkan data kuesioner yang diperoleh, Mayoritas responden telah masuk dalam kategori pola makan yang baik, yaitu sebanyak 43 orang (91.5\%) sedangkan responden dengan kategori pola makan kurang baik sebanyak 4 orang $(8.5 \%)$. Dari seluruh responden didapatkan frekuensi makan 3 kali sehari sebanyak 43 orang $(91,5 \%)$ sisanya sebanyak 4 orang $(8,5 \%)$ makan kurang atau lebih dari 3 kali sehari. Seluruh responden (47 orang) mengkonsumsi karbohidrat setiap harinya. Sebanyak 41 orang $(87,2 \%)$ responden mengkonsumsi protein setiap hari sedangkan sebanyak 6 orang $(12,8 \%)$ tidak mengkonsumsi protein setiap hari. Konsumsi lemak terjadi setiap hari pada 16 (34\%) responden dan yang tidak mengkonsumsi lemak setiap hari sebanyak $31(66 \%)$ responden. Konsumsi vitamin setiap hari didapatkan pada sebanyak 44 $(93,8 \%)$ responden dengan $3(6,4 \%)$ responden yang tidak mengkonsumsi vitamin setiap hari. Mayoritas responden (90,7\%) yang dengan kategori pola makan baik tidak mengalami kejadian KEK dan hanya terdapat 4 responden $(9,3 \%)$ yang dengan kategori pola makan baik namun mengalami kejadian KEK. Dari sebagian besar responden (75\%) yang memiliki kategori pola makan kurang baik mengalami KEK dan hanya 1 responden (25\%) yang mempunyai pola makan kurang baik tidak mengalami KEK. P Stephanie, SKA Kartika - Bali: FK Unud, 2014 - sinta.unud.ac.id

\section{POLA KEJADIAN PADA KEK}

Berdasarkan tingkat pendidikan responden yang paling banyak adalah tamat SD dan yang paling sedikit adalah tamat SMP. Rendahnya pendidikan seorang ibu dapat mempengaruhi terjadinya risiko KEK, hal ini disebabkan karena faktor pendidikan dapat menentukan mudah tidaknya seseorang untuk menyerap dan memahami pengetahuan gizi yang diperoleh (Hardinsyah, 1989).

Dilihat dari hasil mengenai frekuensi makan, sebanyak 43 orang $(91,8 \%)$ telah memiliki frekuensi makan sebanyak tiga kali setiap harinya namun masih ada responden (sebanyak 4 orang) yang memiliki frekuensi makan lebih atau kurang dari tiga kali sehari. Hal ini terjadi oleh karena sebagian responden dengan jawaban tidak makan tiga kali sehari masih menganggap akan gemuk atau takut apabila makan pada malam hari dan lebih dari dua hari sekali dan ada pula yang mengatakan makan lebih dari tiga kali sehari diperlukan untuk menambah tenaga. 
Tidak semua responden yaitu sebanyak 6 orang (12,8\%) mengkonsumsi protein setiap harinya. Data Susenas tahun 1999-2005 mengenai konsumsi pangan masyarakat Indonesia memperlihatkan bahwa konsumsi protein masyarakat Indonesia terutama protein hewani masih kurang. Hal ini ditunjukkan dengan pangsa protein dari pangan hewani rata-rata hanya sekitar $25 \%$. Idealnya, pangsa protein hewani minimal 50\% dari total konsumsi protein untuk mencapai sumber daya manusia yang baik dan mampu bersaing. ${ }^{3}$

Tingkat penghasilan masyarakat sangat mempengaruhi pola makan seseorang. ${ }^{3}$ Disebutkan pada saat terjadinya krisis ekonomi, secara garis besar terjadi penurunan konsumsi pangan. Walaupun secara jumlah berada pada keadaan yang konstan namun terdapat penurunan secara kuantitas. Oleh karena itu, konsumsi protein responden yang pada 6 orang (12,8\%) tidak terjadi setiap hari mungkin disebabkan oleh pendapatan dari responden. Dimana dari hasil penelitian didapatkan 18 orang $(38,3 \%)$ responden masih memiliki pendapatan di bawah UMR.

Konsumsi lemak yang tidak setiap hari diakui oleh 31 orang responden (66\%) sedangkan sisanya sebanyak 16 orang (34\%) 7 mengkonsumsi lemak setiap harinya. Perilaku dapat dipengaruhi oleh berbagai hal salah satunya adalah pengetahuan.7 Dalam hal ini, untuk dapat memperbaiki perilaku masyarakat mengenai pola konsumsi lemak setiap harinya maka perlu diberikan pengetahuan yang lebih kepada responden mengenai pentingnya konsumsi lemak dan fungsi dari masing-masing zat gizi di dalam tubuh. ${ }^{7}$

Faktor yang berperan dalam menentukan status kesehatan seseorang adalah tingkat keadaan ekonomi, dalam hal ini adalah daya beli keluarga. Berdasarkan hasil penelitian, masih terdapat keluarga yang memiliki pendapatan kurang dari UMR. Hal ini tentu sangat berpengaruh terhadap daya beli keluarga tersebut. Kemampuan keluarga untuk membeli bahan makanan antara lain tergantung pada besar kecilnya pandapatan keluarga, harga bahan makanan itu sendiri, serta tingkat pengelolaan sumber daya lahan dan pekarangan. ${ }^{3}$ P Stephanie, SKA Kartika - Bali: FK Unud, 2014 - sinta.unud.ac.id

\section{GIZI UNTUK KEK}

Kerurangan energi kronik yang terjadi pada wanita unsia subur merupakan akibat dari faktor tidak langsug seperti lingkungan dan faktor langsun dari individu manusia yang didukung oleh konsumsi zat gizi sesuai kebutuhan, maka zat gizi yang tersimpan dalam tubuh digunakan 
untuk memenuhi kebutuhan. Apabila keadaan tersebut terus berlangsung dalam jangka waktu lama, maka simpanan zat gizi digunakan sebagai sumber energi dan akan habis, yang pada akhirnya terjadi kemerosotan jaringan dalam tubuh. SAlam, DI Ansyar, MF Satrianegara - Al-Sihah: The Public Health..., 2020 - 103.55.216.56

Asupan Fe: Zat besi adalah mineral yang dibutuhkan untuk membentuk sel darah merah (hemoglobin).Besi dapat diperoleh dengan mengonsumsi hati, daging merah, sayuran hijau, wijen, kuning telur, serealia, dan sarden (Kristiyanasari,2010). Nilai $\mathrm{OR}=1,3$. Yang artinya asupan Fe yang kurang 1,3 Kali lebih berisiko di bandingkan asupan Fe yang cukup. Berkembangnya volume darah selama kehamilan dan tuntutan dari janin yang sedang berkembang memposisikan ibu hamil pada risiko lebih tinggi untuk kekurangan zat besi atau anemia. Sehingga Asupan $\mathrm{Fe}$ ibu hamil dari makanan harus bertambah dan jika asupan Fe ibu hamil kurang maka akan meningkatkan risiko kejadian anemia pada ibu hamil. Penelitian ini sejalan dengan penelitian Indah Lisfi, Joserizal serudji, Husni kadir (2017) yang menyatakan bahwa ada hubungan yang bermakna antara asupan $\mathrm{Fe}$ dengan kejadian anemia dengan nilai $\mathrm{P}=0,008$.

Asupan Zink: Zink sangat penting karena sangat penting untuk pemebelahan sel dan pertumbuhan jaringan dari bayi yang sedang berkembang.Zink merupakan predictor kuat dari hemoglobin. Zink dapat mempengaruhi hemoglobin melalui system enzim zink-dependen, termasuk dalam sintesis hemoglobin dan stimulasi eritropoesis. Hasil penelitian ini menunjukkan hubungan bermakna antara asupan Zink dengan kejadian anemia pada ibu hamil menunjukkan nilai $\mathrm{OR}=1,66$ Yang artinya asupan zink yang kurang 1,66 Kali lebih berisiko di bandingkan asupan zink yang cukup. Penelitian ini sejalan dengan penelitian Hammadah (2016) yang menyatakan bahwa ada hubungan yang bermakna antara asupan zink dengan kejadian anemia dengan nilai $\mathrm{P}=0,005$. $\underline{\mathrm{S} \text { Syarfaini, }} \underline{\mathrm{S} \text { Alam}}, \mathrm{S}$ Aeni, H Habibi, NA Novianti - Al-sihah: The Public Health ..., 2020

\section{ROTI RUMPUT LAUT LAWI-LAWI ALTERNATIF PERBAIKAN GIZI KEK}

Roti rumput laut lawi-lawi subtitusi tempe merupakan salah satu produk diversifikasi pangan lokal dengan pemanfaatan rumput laut lawi-lawi (Ceulerpa racemosa) yang kaya zat besi $(\mathrm{Fe})$ sebesar 9,9 mg/100 gram. Penelitian ini bertujuan untuk mengetahui kandungan zat gizi 
(karbohidrat, protein, lemak, kadar air dan Zat Besi (Fe) serta uji organoleptik pada roti rumput laut lawi-lawi (Ceulerpa racemosa) subtitusi tempe.

Karbohidrat memberikan asupan 60-75\% dari jumlah energi total. Satu gram karbohidrat mengandung 4,1 kalori. Berdasarkan hasil analisis karbohidrat dari 100 g roti rumput laut lawilawi (Ceulerpa racemosa) substitusi tempe menunjukkan bahwa kadar karbohidrat tertinggi pada perlakuan 1: 3 (25\% rumput laut lawi-lawi dan 75\% tempe) sebesar 56,10\%. Hal ini dikarenakan gabungan dari karbohidrat kompleks yang ada pada rumput laut lawilawi dan karbohidrat sederhana yang ada pada tempe pada formulasi ini menghasilkan kandungan karbohidrat total yang tinggi. Kandungan karbohidrat terendah pada perlakuan 1:0 (100\% rumput laut lawi-lawi) sebesar 48,96\%. Hal ini sejalan dengan penelitian Mustadir (2015) dalam penelitiannya Analisis Kandungan Zat Gizi Bakpao Abon Ikan Kembung Jantan dengan Subtitusi Rumput Laut Merah dengan hasil kandungan karbohidrat yang paling tinggi terdapat pada bakpao subtitusi 1:1 dengan komposisi ikan dan rumput laut yang sama dan terendah terdapat pada bakpao subtitusi 1:3 dimana komposisi rumput laut pada perbandingan ini paling banyak dibandingkn pada perbandingan bakpou lainnya. Penelitian ini menyatakan bahwa semakin tinggi komposisi rumput laut pada bakpou maka semakin menurun kadar karbohidratnya namun dengan adanya subtitusi dan perbandingan yang sama maka kadar karbohidratnya jauh lebih tinggi dibandingkan dengan perbandingan komposisi bakpao lainnya karena rumput laut dapat berkontribusi terhadap peningkatan kadar karbohidrat.

Protein memberikan asupan 10-15\% dari jumlah energi total. Setiap 1 gram protein mengandung 4 kalori. Selain digunakan sebagai pengatur, protein dalam tubuh juga digunakan sebagai sumber energi ketika energi yang diperlukan oleh tubuh tidak terpenuhi. Berdasarkan data hasil analisis protein dari 100 gram sampel roti rumput laut lawilawi (Ceulerpa racemosa) substitusi tempe kadar protein tertinggi pada perlakuan 1:3 (25\% rumput laut lawi-lawi dan 75\% tempe) sebanyak $11,42 \%$, selanjutnya pada perlakuan 50:50 sebanyak 10,28\%, kemudian pada perlakuan 0:100 sebanyak 9,94 dan perlakuan 75:25 sebanyak 8,77\%, sedangkan yang paling sedikit pada perlakuan 100:0 sebanyak 8,25\%. Adapun hasil uji kandungan protein pada ke-lima formulasi terlihat menglami kenaikan dari formulasi 100:0 sampai 25:75 hal ini disebabkan karena kandungan protein pada tempe yang lebih tinggi dibandingkan rumput laut lawi-lawi. Namun pada formulasi 0:100 kandungan proteinnya mengalami penurunan karena kandungan protein pada 
tempe tidak dilengkapi dengan rumput laut lawi-lawi. Hal ini sesuai dengan penelitian Munjiah Mustadir (2015) kandungan protein yang paling banyak terdapat pada bakpao subtitusi 3:1 (75\% abon ikan dan 25\% rumput laut) sebanyak 13,72\% dan yang terendah terdapat pada bakpao subtitusi 1:3 (25\% abon ikan dan 75\% rumput laut) sebanyak 9,62\%. Hal ini disbabkan karena rumput laut mengalami proses penjemuran dan pengukusan yang dapat menjadi salah satu faktor terjadinya penurunan kadar protein. Maka semakin tinggi presentase subtitusi rumput laut, kadar proteinnya semakin menurun. Hal ini dapat terjadi karena protein dari rumput laut memiliki senyawa nitrogen yang bersifat volatil, sehingga menguap saat pemanasan.

Lemak dapat menghasilkan energi yang lebih besar, yaitu dari 9 kkal dalam 1 gram lemak dibandingakan dengan protein yang hanya 4 kkal di setiap gramnya. Kebutuhan lemak pada orang dewasa sekitar 30\% dari total kalori. Berdasarkan hasil analisis lemak dari beberapa sampel roti rumput laut lawi-lawi subtitusi tempe menunjukkan bahwa pada roti rumput laut lawi-lawi (Ceulerpa racemosa) substitusi tempe kadar lemak tertinggi pada perlakuan 50:50 sebanyak $8,81 \%$, selanjutnya pada perlakuan 0:100 sebanyak 8,87\% kemudian pada perlakuan 25:75 sebanyak 7,93\% dan perlakuan 100:0 sebanyak 7,71\%, sedangkan yang paling sedikit pada perlakuan 75:25 sebanyak 7,61\%. Kandungan lemak dari roti rumput laut lawi-lawi subtitusi tempe yaitu berasal dari bahan-bahan diantaranya rumput laut lawi-lawi yang memiliki kandungan lemak sebesar 0,08 - 1,9 gram dalam 100 gramnya, tempe sebesar 8,8 gram lemak dalam 100 gramnya, tepung terigu 1 gram dalam 100 gramnya, susu bubuk 28 gram dalam 100 gramnya dan telur 11,5 gram dalam 100 gramnya. Adapun hasil uji kandungan lemak pada ke-lima formulasi yang tidak berbeda jauh namun berfluktuatif disebabkan karena perbedaan jenis asam lemak pada rumput laut lawi-lawi dan tempe serta perbedaan titik leburnya. Khusus untuk lemak tak jenuh ganda, nutrisi ini bisa diperoleh dari sumber-sumber makanan dengan kandungan omega-6 dan omega-3, sedangkan untuk lemak tak jenuh tunggal diperoleh dengan mengonsumsi sumber makanan berkandungan omega-9 dan keduanya ada pada rumput laut lawi-lawi (Sanjaya, 2016). Sedangkan asam lemak tidak jenuh majemuk tinggi ada pada tempe (Badan Standarisasi Nasional, 2012).

Zat Besi merupakan mikronitrien dan unsur vital yang dibutuhkan tubuh dalam pembentukan hemoglobin serta komponen penting pada sistem enzim pernafasan. Pada metabolisme zat besi dapat diketahui komposisi dan distribusi besi dalam tubuh manusia, cadangan 
besi tubuh, siklus besi, absorbsi besi dan transportasi besi. Berdasarkan hasil analisis kadar zat besi dari beberapa sampel menunjukkan bahwa pada roti rumput laut lawi-lawi (Ceulerpa racemosa) substitusi tempe kadar zat besi tertinggi pada perlakuan $50: 50$ sebanyak $24,7860 \mathrm{mg} / \mathrm{kg}$, selanjutnya pada perlakuan 100:0 sebanyak $21,5841 \mathrm{mg} / \mathrm{kg}$ kemudian pada perlakuan 75:25 sebanyak 20,7864 mg/kg dan perlakuan $25: 75$ sebanyak $17,1827 \mathrm{mg} / \mathrm{kg}$, sedangkan yang paling sedikit pada perlakuan 0:100 sebanyak $13,9195 \mathrm{mg} / \mathrm{kg}$. S Syarfaini, DS Damayati, $\underline{A}$ Susilawaty, $\underline{\mathrm{S}}$ Alam... - ... Health Science Journal, 2019 


\section{DAFTAR PUSTAKA}

1. Bisara, D., Supraptini, S., \& Afifah, T. (2003). Status Gizi Wanita Usia Subur (Wus) dan Balita di Indonesia Menurut Data Skrt 2001. Indonesian Bulletin of Health Research, 31(3), 65995.

2. Syarfaini, S., Alam, S., Aeni, S., Habibi, H., \& Novianti, N. A. (2020). Faktor Risiko Kejadian Anemia Pada Ibu Hamil Di Wilayah Kerja Puskesmas Sudiang Raya Kota Makassar. Al-sihah: The Public Health Science Journal, 11(2).

3. Stephanie, P., \& Kartika, S. K. A. (2014). Gambaran Kejadian Kurang Energi Kronis Dan Pola Makan Wanita Usia Subur Di Desa Pesinggahan, kecamatan Dawan, Klungkung. Bali: FK Unud.

4. Putri, M. C. (2017). Hubungan Asupan Makan dengan Kejadian Kurang Energi Kronis (KEK) pada Wanita Usia Subur (WUS) di Kecamatan Terbanggi Besar Kabupaten Lampung Tengah.

5. Alam, S., Ansyar, DI, \& Satrianegara, MF (2020). Pola makan dan riwayat pendidikan pada wanita usia subur. Al-Sihah: Jurnal IImu Kesehatan Masyarakat, 12 (1), 81-91.

6. Syarfaini, S., Damayati, D. S., Susilawaty, A., Alam, S., \& Humaerah, A. M. (2019). Analisis Kandungan Zat Gizi Roti Rumput Laut Lawi-Lawi (Ceulerpa racemosa) Subtitusi Tempe Sebagai Alternatif Perbaikan Gizi Masyarakat. Al-sihah: The Public Health Science Journal, 11(1). 